\title{
The Impact of Government Size on Economic Growth
}

\author{
Ashraf Lotfi Elsayed \\ Department of economics, Faculty of commerce, \\ Tanta University \\ ashraflotfey@gmail.com
}




\title{
The Impact of Government Size on Economic Growth \\ Ashraf Lotfi Elsayed \\ Department of economics, Faculty of commerce, Tanta University ashraflotfey@gmail.com
}

\begin{abstract}
Driven by the observed growing government expenditure in Egypt, this study sets to test the non-linear relationship between government expenditure and economic growth and it tries to examine the existence of Armey curve in Egypt. We employ the smooth transition regression models (STR). The results show a non-linear relationship of the Armey curve in Egypt, in which the threshold effect corresponding to government final consumption expenditure share in GDP of about $13 \%$.
\end{abstract}

JEL Classification: E62, O40, C22

Keywords: Government size, Economic growth, Smooth threshold regression model

\section{1- INTRODUCTION}

Economic growth has always been at the heart of the literary works in development economics, and it is one of the most attractive subjects in macroeconomics. Among many factors that determine economic growth, government size is our particular interest in this study. The Solow growth approach was used in many empirical studies, although it dealt with all economic growth sources as exogenous factors. As a result, government policy has no effect on long run economic growth. In contrary to the exogenous growth models, the endogenous growth models [ Romer (1986) and Barro (1990)] indicate that the determinants of growth are endogenous to the model. The determination of long run growth within the model, rather than by some exogenous variables (e.g. technological progress). (Barro and Sala-i-Martin, 1995, 38) 
Theoretically, the relationship between government spending and economic growth has been studied within via the Armey curve (Armey et al., 1995), the Rahn Curve (Rahn and Fox, 1996), and the "BARS" curve (Barro [1989], Armey et al. [1995], Rahn [1996], and Scully [1994] ). Armey curve, which explain the rule of government spending on economic growth, shows that there is a positive relationship between government expenditure and economic growth before certain point. And after this point the relation will become negative.

Fig 1. Armey Curve

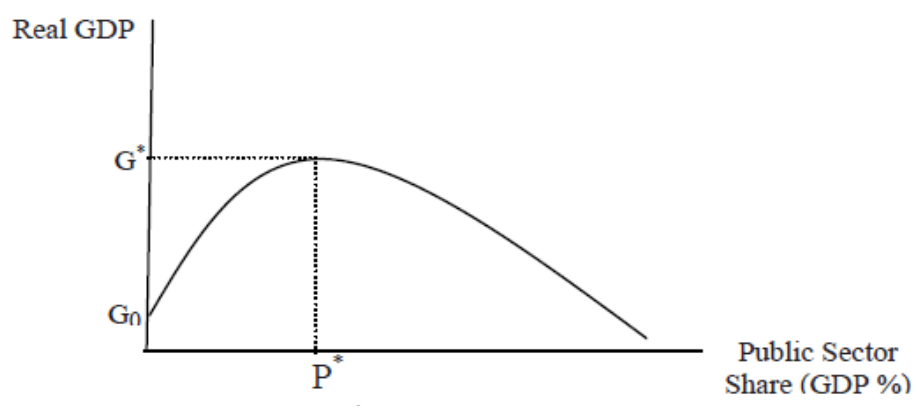

There are two points of view to interpret the impact of government sector on economic growth. The first point maintains that over expanding government sector tends to crowd out private sector investment, leading in the end to hinder economic growth. Generally, the negative relationship between government size and economic growth may be because of many reasons: costly financing methods (print new money, borrowings...), crowding out of production private investment, (government spending displaces private sector activities), transfer payments (welfare programs, grants, unemployment insurance) may discourages economic decisions. In addition, transfer payments may provide an incentive to lower savings rate, hindering resource allocation and inhibiting innovations Landau (1983), Engen and Skinner (1991), Folster and Henrekson (2001), and Dar and AmirKhalkhali (2002). The second point attributes to the government a non-negligible rule to play in mobilizing necessary physical and human capital that are important to boost economic growth.

The aim of this paper is to examine the growth-government size relationship in Egypt for the 1983 - 2012 period. The remainder of this paper is organized as follows: section 2 devotes to literature review about 
government expenditure and economic growth. Section 3 presents model specification and data description. Section 4 focus on empirical results, and finally a brief conclusion will be presented in section 5 .

\section{2- LITERATURE REVIEW}

As brief indicated in Table 1, many empirical studies, depending on cross-section data, such as Landau (1983), Ram (1986), Grier and Tullock (1989), Romer (1990), Barro (1990, 1991), Levine and Renelt (1992), Devarajan et al. (1996), and Sala-i- Martin (1997) studied the effect of government spending on economic growth, and they found varied evidence. Landau (1983), Engen and Skinner (1991), Folster and Henrekson (2001), and Dar and AmirKhalkhali (2002) find a negative relationship between government size and economic growth. This negative relationship is result of crowd-out effect to private investment. In addition, government expenditure may distort the allocation of resources.

On the contrary, Ram (1986), Kormendi and Meguire (1986) and Wu et al (2010) examined the causal relationship between government expenditure and economic growth using either OLS method or Granger causality test, and they found that there is a positive effect of government spending on economic growth. They believe that government expenditure can support private investment through improving the investment environment. In addition, depending on Keynesian view, expanding on government expenditure has positive effect on investors' expectations.

Easterly and Rebela (1993) found a mix results, while government expenditure on specific sectors (e.g. transport, education, and communication) is positively related with economic growth, total public investment is negatively related with growth.

These inconsistent results of government expenditure (size) on economic growth may be due to non-linear relationship Chen and Lee (2005). Whereas, Henrekson (1993) argues that earlier findings from time series studies are likely to be spurious because they did not test the stationarity hypothesis of the data. Vezirl et al (2011) have carried out a study that utilized Hansen's threshold regression (1996). They found a non-linear relationship between economic growth and government size. 
Vedder and Gallaway (1998) investigate that the relationship between government size and economic growth has an inverse U-shape curve. They found that if government expenditure is greater than $15 \%$, then the relationship between them is negative. However, the relationship turns to positive when government expenditure get smaller than $15 \%$. This asymmetric relationship is known as Armey curve (Figure 1).

Table 1. Literature review of the relationship between government size and economic growth

\begin{tabular}{|c|c|c|c|}
\hline Author (s) & $\begin{array}{l}\text { government size } \\
\text { variable }\end{array}$ & Subject & Relationship \\
\hline Landau (1983) & $\begin{array}{l}\text { government } \\
\text { consumption }\end{array}$ & $\begin{array}{l}96 \text { developed } \\
\text { Countries. } \\
1960-1977\end{array}$ & $\begin{array}{l}\text { Negative } \\
\text { relationship }\end{array}$ \\
\hline $\begin{array}{l}\text { Dar, } \\
\text { Amirkhakhla } \\
(2002)\end{array}$ & $\begin{array}{l}\text { Total } \\
\text { government } \\
\text { outlays /GDP }\end{array}$ & $\begin{array}{l}19 \quad \text { OECD } \\
\text { countries, } \\
1971-1999\end{array}$ & $\begin{array}{l}\text { Negatively } \\
\text { relationship } \\
\text { between TFP } \\
\text { and government } \\
\text { size }\end{array}$ \\
\hline $\begin{array}{l}\text { Abo Bader and } \\
\text { Abo Qarn } 2003\end{array}$ & $\begin{array}{l}\text { government } \\
\text { consumption }\end{array}$ & $\begin{array}{l}\text { Egypt, Israel, } \\
\text { and Syria }\end{array}$ & $\begin{array}{l}\text { Negative } \\
\text { relationship }\end{array}$ \\
\hline Chandra 2004 & $\begin{array}{l}\text { Investment and } \\
\text { total expenditure }\end{array}$ & $\begin{array}{ll}\text { India } & 1950- \\
1996\end{array}$ & $\begin{array}{l}\text { Negative relation } \\
\text { in short run. And } \\
\text { no relation in } \\
\text { long run }\end{array}$ \\
\hline $\begin{array}{l}\text { Loizides \& } \\
\text { Vamvoukas } \\
2005\end{array}$ & $\begin{array}{l}\text { Total } \\
\text { expenditure/ } \\
\text { GDP }\end{array}$ & $\begin{array}{l}\text { Greece, } \begin{array}{r}\mathrm{UK} \\
\text { and Ireland } \\
(1950-1995)\end{array}\end{array}$ & $\begin{array}{l}\text { Government size } \\
\text { causes economic } \\
\text { growth in all } \\
\text { countries except } \\
\text { Greece in short } \\
\text { and long run as } \\
\text { well. }\end{array}$ \\
\hline $\begin{array}{ll}\text { Ahmed } & \& \\
\text { Ahmed } 2005 & \end{array}$ & $\begin{array}{l}\text { Government } \\
\text { final } \\
\text { consumption/ } \\
\text { GDP }\end{array}$ & $\begin{array}{l}\text { D-8 countries } \\
1973-2003\end{array}$ & $\begin{array}{l}\text { No correlation in } \\
\text { short run. }\end{array}$ \\
\hline Wu et al. (2010) & $\begin{array}{l}\text { Real government } \\
\text { expenditures }\end{array}$ & $\begin{array}{l}182 \text { countries. } \\
1950-2004\end{array}$ & $\begin{array}{l}\text { Positive } \\
\text { bidirectional } \\
\text { relationship }\end{array}$ \\
\hline
\end{tabular}




\begin{tabular}{|c|c|c|c|}
\hline $\begin{array}{l}\text { Safdari et al. } \\
(2011)\end{array}$ & $\begin{array}{ll}\text { The ratio of } \\
\text { government } \\
\text { expenditure to } \\
\text { GDP }\end{array}$ & $\begin{array}{l}\text { Iran. } \\
2008\end{array}$ & $\begin{array}{l}\text { Negative effect } \\
\text { on GDP }\end{array}$ \\
\hline Christie 2014 & $\begin{array}{l}\text { Total } \\
\text { government } \\
\text { spending } \\
\text { (excluding } \\
\text { interest } \\
\text { payments) }\end{array}$ & $\begin{array}{l}136 \text { countries. } \\
1971-2005\end{array}$ & Negative effect \\
\hline $\begin{array}{l}\text { Varoudakis et al. } \\
2007\end{array}$ & & $\begin{array}{l}25 \text { countries - } \\
1992-2004\end{array}$ & $\begin{array}{l}\text { Negative } \\
\text { relationship }\end{array}$ \\
\hline Herath. 2012 & $\begin{array}{l}\text { total government } \\
\text { expenditure. }\end{array}$ & $\begin{array}{l}\text { Sri Lanka. } \\
1959-2009\end{array}$ & $\begin{array}{l}\text { Positive } \\
\text { relationship }\end{array}$ \\
\hline $\begin{array}{l}\text { Mehrara \& } \\
\text { Keikha. } 2012\end{array}$ & $\begin{array}{l}\text { total government } \\
\text { expenditure. }\end{array}$ & $\begin{array}{ll}\text { Iran. } & 1967- \\
2007\end{array}$ & $\begin{array}{l}\text { Positive } \\
\text { relationship }\end{array}$ \\
\hline $\begin{array}{l}\text { Rajabi \& } \\
\text { Muhammed. } \\
2014\end{array}$ & $\begin{array}{l}\text { Government } \\
\text { consumption }\end{array}$ & $\begin{array}{l}\text { ASEAN-5. } \\
1980-2006\end{array}$ & Negative effect \\
\hline
\end{tabular}

\section{3- DATA AND MODEL}

The data set in this study relates to Egypt and consists of 120 quarterly time series observations covering the time period 1983:Q1 to 2012:Q4. We use gross domestic product growth (GROWTH), and as a measure of government size (GOVSIZE), general government final consumption expenditure to gross domestic product. Government consumption includes all government current expenditures for purchases of goods and services (including compensation of employees). It also includes most expenditures on national defense and security, but excludes government military expenditures that are part of government capital formation. All data are transformed to logarithmic form.

Transition dynamics based on continuous transition that allows for smooth changes during the transition. Most of economic variables take time to change from one regime to another, and not in sudden abrupt changes.

The smooth transition regression models (STR) have been arisen since seminal study of Bacon and Watt (1971) and followed by further 
studies such as Granger and Teräsvirta (1993), Franses and van Dijk (2000), and van Dijk et al (2002).

Following Teräsvirta (2004), the standard STR model can be written as

$$
y_{t}=\varphi^{\prime} X_{t}+\theta^{\prime} X_{t} G\left(\gamma_{s} c_{y} s_{t}\right)+u_{t}, \quad t=1, \ldots \ldots, T
$$

Where $X_{t}$ is a vector of predictor variables equals $\left(1, y_{t-1}, \ldots, y_{t-p}\right.$, $\left.x_{t}, \ldots \ldots, x_{q t}\right) . \varphi^{x}=\left(\varphi_{11}, \ldots, \varphi_{1 m}\right)$ and $\theta^{t^{t}}=\left(\theta_{\downarrow} 21_{j} \ldots \ldots, \theta_{\downarrow} 2 m\right)$ are $\mathrm{m} X 1$ parameters vectors. $\boldsymbol{u}_{\boldsymbol{t}}$ is an error with mean equal zero and a constant variance. And $G\left(\gamma_{s} c_{s} s_{t}\right)$ is a transition function bounded between 0 and 1, and it depends on the slope parameter; the vector of location parameters which equals $\left(c_{1} 1 \ldots \ldots \ldots\left[c_{1} k\right)\right]^{\text {t } r}$ where $c_{1} \leq \cdots \leq c_{k}$; and transition variable $s_{t}$ that can be part of $X_{t}$ or another variable. The shape of transition function is assumed to be a logistic function.

$$
, y>0
$$

The most common choices for $\mathrm{K}$ are $\mathrm{K}=1$ (LSTR1) and $\mathrm{K}=2$ (LSTR2).

STR modelling cycle consists of three basic steps:

The first step is identifying the model. This step starting by using VAR framework to test the stationarity, testing the nonlinear relationship between variables, choosing the transition variable (st), and deciding whether LSTR 1 or LSTR2 model should be used.

At this stage, and in order to study the nonlinear relationship models LSTRi, the following regression model is used:

$$
y_{t}=\beta_{o}^{x} z_{t}+\sum_{j=1}^{3} \beta_{j}^{x} \tilde{z}_{t} s_{t}^{j}+u_{t}^{*} \quad \mathrm{t}=1, \ldots \ldots, \mathrm{T}
$$

Where $z_{t}=\left(1, \tilde{z}_{t}\right), \beta_{j}^{*} \mathrm{j}=1,2,3$, is of the form $\widetilde{\beta}_{j}$, where, $\widetilde{\beta}_{j} \neq 0$ is a function of $\theta$ and $c$. The null hypothesis of linearity is:

$$
\mathrm{H}_{0}: \beta_{1}=\beta_{\mathrm{z}}=\beta_{\mathrm{a}}
$$

The $\mathrm{F}$ test is used to test the hypothesis. After rejecting the linearity hypothesis, the following tests should be performed for selecting between LSTR1 and LSTR2 models:

Test $\mathrm{H}_{04}: \beta_{\mathrm{a}}=0$ 
Test $\mathrm{H}_{03}:\left(\beta_{\mathbf{2}}=0 \mathbf{0} \beta_{\mathrm{s}}=\mathbf{0}\right)$

Test $\mathrm{H}_{02}:\left(\beta_{1}=\mathbf{0} / \beta_{2}=\beta_{3}=\mathbf{0}\right)$

In case of rejecting $\mathrm{H}_{03}$, one choses the LSTR2 model. Otherwise, selects LSTR1 model. The second step is estimating the parameters of STR model using conditional maximum likelihood. In this paper we use BFGS (Broyden, Fletcher, Goldfarb and Shanno (1970)) algorithm that is very robust and efficient algorithm (Skajaa, 2010).

The final step is evaluating of the estimated STR model. This step usually involves besides graphical analysis various diagnostic tests such as no error autocorrelation, no additive nonlinearity, and test of parameter constancy.

\section{4- RESULTS}

We start our analysis by testing the data for stationarity using augmented dickey-fuller test (ADF) and ADF type test of Saikkonen and Lütkepohl (2002) which take into account of structural break.

Table 2 Unit root tests

\begin{tabular}{|c|c|c|c|c|}
\hline & $\begin{array}{l}\text { ADF: } \\
\text { Without } \\
\text { time trend }\end{array}$ & $\begin{array}{l}\text { ADF:With } \\
\text { time trend }\end{array}$ & $\begin{array}{l}\text { ADF: with } \\
\text { constant }\end{array}$ & $\begin{array}{l}\text { Saikkonen \& } \\
\text { Lütkepohl } \\
\text { (S\&L) } \\
(2002)\end{array}$ \\
\hline GOVSIZE & $7.0376 * * *$ & $3.6849 * *$ & $6.0998 * * *$ & \\
\hline Growth & 1.2538 & -1.5493 & 1.0417 & $-8.1953 * * *$ \\
\hline
\end{tabular}

The results reported in table (2) show that the null hypothesis of unit root is rejected for the two variables using both tests (ADF and S \& L). Thus, all level variables are stationary or $\mathrm{I}(0)$.

In order to estimate STR model, we start with specifying an adequate linear model and determining the number of lagged variables in the model. Based on AIC and SBC criteria; the optimal lag length between economic growth and government size is 2 lags. Next, linearity null hypothesis tests against the alternative one of the STR model. The results reported in table (3) show that, based on F statistics; we can reject the null 
hypothesis of linearity at $1 \%$ level of significance. In addition, based on results reported in table (3), we consider GOVSIZE (government expenditure) as the transition variable. Figure 2 shows the estimated logistic transition function against this transition variable .

Table 3 The results of the linearity tests against the STR model

\begin{tabular}{lccccc}
\hline \multicolumn{1}{c}{ Variable } & $\mathrm{F}$ & $\mathrm{F} 4$ & $\mathrm{~F} 3$ & $\mathrm{~F} 2$ & $\begin{array}{c}\text { Suggested } \\
\text { model }\end{array}$ \\
\hline GROWTH $_{(\mathrm{t}-}$ & $3.028^{-18}$ & $5.144^{-1}$ & $3.019^{-7}$ & $6.169^{-16}$ & LSTR1 \\
& & & & & \\
1) $_{\text {GROWTH }}^{(\mathrm{t}-}$ & $3.079^{-18}$ & $5.070^{-1}$ & $3.577^{-7}$ & $5.372^{-16}$ & LSTR1 \\
2) $_{\text {GOVSIZE }_{(\mathrm{t})}{ }^{*}}$ & $3.041^{-22}$ & $9.729^{-5}$ & $3.493^{-2}$ & $2.405^{-21}$ & LSTR1 \\
GOVSIZE $_{(\mathrm{t}-1)}$ & $1.439^{-18}$ & $1.525^{-3}$ & $3.098^{-1}$ & $6.320^{-20}$ & LSTR1 \\
GOVSIZE $_{(\mathrm{t}-2)}$ & $1.598^{-18}$ & $1.748^{-3}$ & $2.941^{-1}$ & $6.543^{-20}$ & LSTR1 \\
Trend & $3.699^{-19}$ & $3.932^{-3}$ & $2.940^{-1}$ & $8.706^{-9}$ & LSTR2 \\
\hline
\end{tabular}

The next step is estimating STR model. Due to the nonlinear nature of these types of models, we have to obtain appropriate starting values for the slope parameter " $\gamma$ " and the transition variable " $c$ ". using grid search within ranges [0.43,8.02] and [5.50,20], the selected initial values for the $\gamma$ and $c$ are 7.1334 and 13.5931 respectively. Considering these initial points, the results of the first $(\mathrm{G}=0)$ and second regime $(\mathrm{G}=1)$ are presented in table (4).

Table 4 The estimation results of the STR model

\begin{tabular}{llc}
\hline & Linear part & Nonlinear part \\
\hline constant & $3.06122^{*}$ & $3.21236^{*}$ \\
& $(3.9349)$ & $(2.8010)$ \\
GROWTH $_{\mathrm{t}-1}$ & $0.86609^{*}$ & $-0.12433^{*}$ \\
& $(22.9962)$ & $(-2.2917)$ \\
GOVSIZE $_{\mathrm{t}}$ & $19.93581^{*}$ & $-19.93582^{*}$ \\
& $(3.6781)$ & $(-3.6381)$ \\
GOVSIZE $_{\mathrm{t}-1}$ & $-21.33156^{*}$ & $26.60931^{*}$ \\
& $(-4.0885)$ & $(4.0563)$ \\
\hline
\end{tabular}




\begin{tabular}{lc}
\hline Gamma & 7.3352 \\
C1 & 13.1379 \\
Adjusted R2 & 0.9338 \\
ARCH-LM & 17.1736 \\
Jarque-Bera & 2.3545 \\
Breusch-Godfrey & 1.2434 \\
\hline
\end{tabular}

As shown in table (4), the slope parameter which represent the speed to switch from one regime to another, equals to 7.3352 which denotes to the rapid transition of regimes. According to the transition value (13.14), if the size of government is higher than this value, then we entered the second regime.

Thus, the transition function $G\left(\gamma_{s} c_{y} s_{t}\right)$ is specified as below for the two extreme states, $\mathrm{G}=0$ and $\mathrm{G}=1$ :

The first regime $(\mathrm{G}=0)$ :

$$
\begin{gathered}
\text { GROWTH }_{t}=3.061+0.866 \text { GROWTH }_{t-1}+0.199 \text { GOVSIZE }_{t}+0.213 \\
\text { GOVSIZE } \\
t-1
\end{gathered}
$$

The second regime $(\mathrm{G}=1)$

$$
\begin{gathered}
\text { GROWTH }_{t}=-2.152+0.073 \text { GROWTH }_{t-1^{-}} 0.098 \text { GOVSIZE }_{t}-0.794 \\
\text { GOVSIZE } \\
t-1
\end{gathered}
$$


Fig. 2 logistic transition function related to regime changes

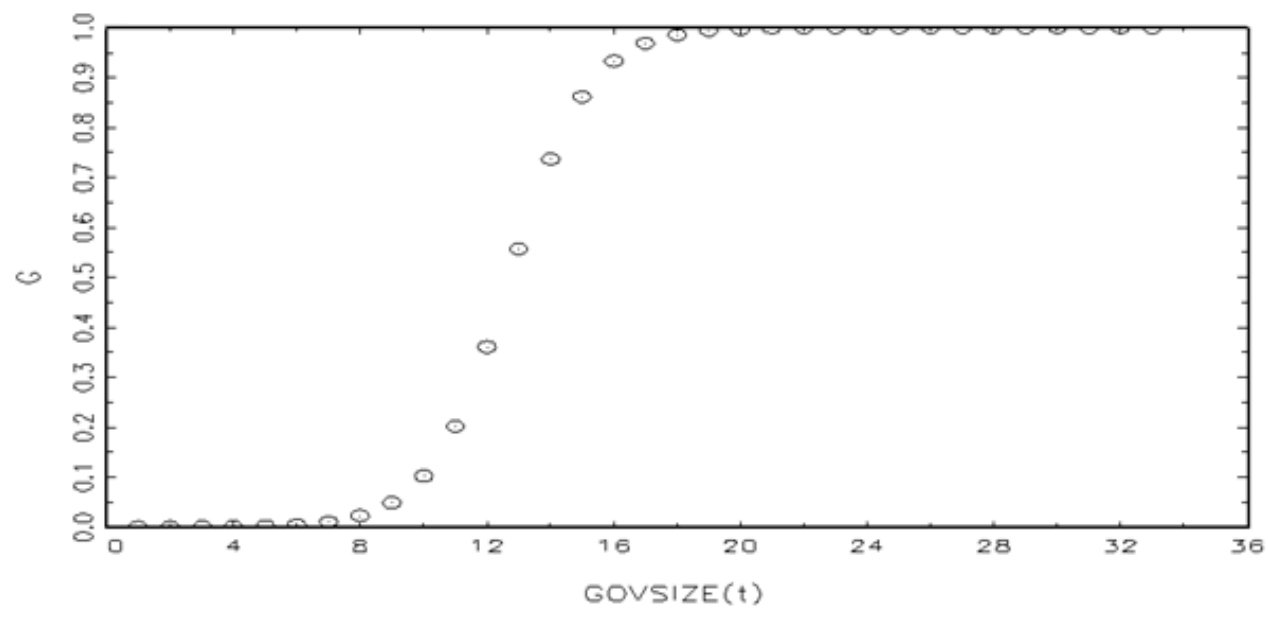

The results of both extreme regimes show that the size of government has a positive impact on economic growth in Egypt in the first extreme regime, while this effect becomes negative effect in the second regime. In other words, when government expenditure is small, the threshold is less than $13.14 \%$, the relationship between government expenditure and economic growth is significantly positive (since the sum of the estimated coefficients of government consumption is equal 0.412). However, when total government expenditure is large, the threshold is higher than $13.14 \%$, the relationship between government expenditure and economic growth becomes negative (the sum of government size coefficient equals -0.892).

To check the goodness of STR model diagnostic tests are carried out which include ARCH-LM test for heteroskedasticity, Jarque-Bera test for normality, and Breusch-Godfrey Lagrange multiplier test for serial correlation. The results of diagnostic rests reported in table (4). The ARCH-LM test are implying the rejection of null hypothesis; absence of heteroscdasticity. Also Jarque-Bera test is significant, confirming the normality of errors. The last diagnostic test is Breusch-Godfrey Lagrange multiplier that shows the absence of serial correlation. 


\section{5- CONCLUSIONS}

Given the importance of the impact of government size on economic growth, and the controversial empirical and theoretical literatures on this relationship, this study further to test the nonlinear relationship between these variables in Egypt over 1983-2012 under notion of" Armey curve". For testing the existence of a threshold effect between government total consumption and economic growth, this study has used smooth threshold regression (STR) model.

The results show that the magnitude of government size on economic growth varies according to regimes. When the government size is smaller than the threshold limit value, economic growth is nourished by expanding government expenditure. but if the government size is larger than the threshold value, then the economic growth decreases. Thus, policy makers should make control about government size, because economic growth is sensitive to government size. 


\section{REFERENCES}

1. Abu-Bader, S. and Abu-Qarn, A. (2003). Government Expenditures, Military Spending and Economic Growth: Causality Evidence from Egypt, Israel and Syria, Journal of policy Modeling, 25(6), 567-583.

2. Armey, D. and Armey R. (1995). The Freedom Revolution: The New Republican House Majority Leaders Tells why Big Governments failed, Why Freedom works, and How we will rebuild America, Wasgington D.C.; Regnery Publishing Inc.

3. Barro, R. (1990). Government Spending in a Simple Model of Endogenous Growth, Journal of Political Economics, 98, S103S125.

4. Barro, R. J. (1989). A Cross-Country Study of Growth, Saving and Government, NBER Working Paper No. 2855.

5. Barro, R. J. and Sala-i-Martin, X. (1995). Economic Growth, New York: McGraw-Hill.

6. Barro, R. (1991). Economic Growth in a Cross Section of Countries, Quarterly Journal of Economics, 106(2), 407-443.

7. Broyden, C. G. (1970). The Convergence of a Class of Double Rank Minimization algorithms 2 the New Algorithm. Journal of the Institute of Mathematics and its Applications. 6, 222-231.

8. Chandra, Kanchan. (2004). Why Ethnic Parties Succeed: Patronage and Ethnic Head Counts in India. Cambridge: Cambridge University Press.

9. Chen, S. T. \& Lee, C. C. (2005). Government size and economic growth in Taiwan: A threshold regression approach, Journal of Policy Modeling, 27, 1051-1066.

10. Christie, T. (2012). The Effect of Government Spending on Economic Growth: Testing the Non-linear Hypothesis. Bulletin of Economic Research. 66(2). 183-204.

11. Dar, A. and Amirkhalkhali, S. (2002), Government Size, Factor Accumulation, and Economic Growth: Evidence form OECD Countries, Journal of Policy Modelling, 24, 679-692.

12. Devarajan, S., Vinaya, S and Heng-fu Z. (1996). The Composition of Public Expenditure and Economic Growth. Journal of Monetary Economics, 37(2), 313-344.

13. Easterly, W. \& Rebelo, S. (1993). Fiscal Policy and Economic Growth: An Empirical Investigation, Journal of Monetary Economics, 32(3), 417-458. 
14. Engen E. M., and Skinner J., (1992). Fiscal Policy and Economic Growth, NBER Working Paper No. 4223.

15. Fletcher, R. (1970). A New Approach to Variable Metric Algorithms. Computer journal. 13. 317-322.

16. Fölster, S, and Henrekson, M (2006). Growth Effects of Government Expenditure and Taxation in Rich Countries: A Reply. European Economic Review 50 (1): 219-222.

17. Franses, P.H., and van Dijk, D., (2000). Nonlinear Time Series Models in Empirical Finance. Cambridge: Cambridge University Press.

18. Goldfarb, D. (1970). A Family of Variable Metric Updates Derived by Variational Means. Mathematics of Computation. 24. $1-22$.

19. Granger, C.W.J., Terasvirta, T., (1993). Modelling Nonlinear Economic Re-lationships. Oxford: Oxford University Press.

20. Grier K., Tullock G. (1989). An Empirical Analysis of Crossnational Economic Growth, 1951-1980, Journal of Monetary Economics, 24, 48-69.

21. Henrekson ， M. (1993). Wagner's Law - a Spurious Relationship?, Public Finance, 48, 406-415.

22. Herath, S. (2012). Size of Government and Economic Growth: A Nonlinear Analysis, Economic Annals, 57(194), 7-30.

23. Landau, D. (1983). Government Expenditure and Economic Growth: A Cross-Country Study, Southern Economic Journal, 49 (3), 783-792.

24. Levine,R. and D. Renelt, (1992), A Sensitivity Analysis of Crosscountry Growth Regressions, American Economic Review. 82, 942-963.

25. Loizides, J., and G.Vamvoukas, (2005). Government Expenditure and Economic Growth: Evidence from Trivariate Causality Testing. Journal of Applied Economics. 8, 125-152.

26. Mrhrara, M., Keikha, A. (2012). Government Size and Economic Growth in Iran. International Journal of Economics and Research. 3(2).52-60.

27. Poot, J. (2000). A Synthesis of Empirical Research on the Impact of Government on Long Run Growth. Growth and Change 31, 516-546.

28. Rahn R., and Fox H. (1996). What Is the Optimum Size of Government?, Vernon K. Krieble Foundation.

29. Rajabi, E. \& Muhammad, J. (2014). Does The Government Size Cause economic Growth?: Empirical Evidence from Selected ASEAN Countries, Economic Studies journal, Bulgarian 
Academy of Sciences - Economic Research Institute, issue 1, 320.

30. Ram, R. (1986), Government Size and Economic Growth: A New Framework and Some Evidence from Cross-Section and Time Series Data, American Economic review, 76, 191-203.

31. Romer, P. (1990), Endogenous Technological Change. Journal of Political Economy, 98 (5), 71-102.

32. Romer, Paul M. (1986). Increasing Returns and Long Run Growth, Journal of Political Economy, 94, 1002-37.

33. Safdari M. M., Mehrizi, A., \& Elahi. (2011). Government Size and Economic Growth in Iran. International Research Journal of Finance and Economics, 1-7.

34. Saikkonen, P., Lutkepohl, H., (2002). Testing for a Unit Root in a Time Series with a Level Shift at Unknown Time. Econometric Theory 18, 48-313.

35. Scully G.W. (1994), What Is the Optimal Size of Government in the United States?, National Centre for Policy Analysis - Policy Report, No. 188.

36. Shanno, D. F. (1970). Conditioning of Quasi-Newton Methods for Function Minimization. Mathematics of Computation. 24. 647650.

37. Skajaa, Anders, (2010), Limited Memory BFGS for Non-smooth Optimization, Master thesis, New York University.

38. Van Dijk, D., Teräsvirta, T. and Franses, P.H., (2002). Smooth Transition Autoregressive Models : A Survey Of Recent Developments. Econometric Reviews 21(1), 1-47.

39. Varoudakis, A., Tiongson, E. R., \& Pushak, T. (2007). Public finance, governance, and growth in transition economies: Empirical evidence from 1992-2004, Policy Research Working Paper Series No. 4255. Washington, DC: World Bank.

40. Vedder, R. K. \& Gallaway, L. E. (1998). Government Size and Economic Growth, paper prepared for the Joint Economic Committee of the US Congress, 1-15.

41. Wu, S., Tang J., and Lin E. (2010), The Impact of Government Expenditure on Economic Growth: How Sensitive to the Level of Development?, Journal of Policy Modeling, 23, 1-18. 